\title{
ESKİ HARFLİ BİR ÇOCUK GAZETESİ: SADÂKAT / ETFÂL ${ }^{*}$
}

\author{
Arș. Gör. Aliye Nur ERCAN* \\ Yrd. Doç. Dr. Şerife AKPINAR ${ }^{* *}$
}

ÖZ: Eski harfli çocuk gazetelerinden biri olan Sadâkat/Etfâl, 1875 yılında İstanbul'da Tahsin tarafından çıkarılmıştır. Çocuklara özel olarak haftada bir çıkarılan bu gazete, yayımlandığı dönemde oldukça ilgi görmüştür. "Sadâkat" ismiyle altı sayı çıkan gazete, daha sonra "çocuklar" anlamına gelen "Etfâl" ismini almış ve yeni ismiyle on yedi sayı daha çıkmıştır. Toplamda yirmi üç sayı yayımlanmıştır. Her bir sayı dört sayfadan oluşmuş ve önce 10 paraya daha sonraları da 20 paraya satılmıştır. Sadâkat/Etfâl'de sade bir dille matematikten tarihe, fizikten dinî bilgilere, coğrafyadan hayvan tanıtımlarına kadar pek çok konuya yer verilmiştir. Ayrıca metinlerle çocuklara millî ve evrensel değerler aktarılmaya çalışılmış; hazırlanan sorularla okul eğitimlerine destek olunmuştur. İlk resimli çocuk gazetesi unvanına sahip olan Sadâkat/Etfâl, bu yönüyle sonraki yıllarda çıkarılan çocuk gazete ve dergilerine de öncülük etmiştir.

Anahtar Kelimeler: Sadâkat, Etfâl, çocuk gazetesi, resim

\section{One of the Kid's Journal in The Ottoman Turkish: Sadâkat/ Etfâl}

ABSTRACT: One of the kid's journals written in ottoman Turkish was called Sadakat/Etfaland had been published in 1875 in İstanbul by Tahsin. This journal had been published weekly, especially for kids, had attracted much attention in that era. With the name "Sadakat" it had six

* $\quad$ Bu makale, birinci yazarın, ikinci yazar yönetiminde çalıştığı "Etfâl Gazetesinin Metin ve Değerler Eğitimi Açısından İncelenmesi" (2014) adlı yüksek lisans tezinden yararlanılarak hazırlanmıştır.

* Necmettin Erbakan Üni. A.K. Eğt. Fak. Türkçe Eğt. Böl., ercanaliyenur@gmail.com

** Necmettin Erbakan Üni. A.K. Eğt. Fak. Türkçe Eğitimi Böl., sakpinar07@gmail.com 
copies, and then it had been renamed as "Etfal" meaning "children" and had seventeen more copies. The total number of the copies had been twenty three. Every copy consisted of four pages and at first it was sold for ten para/cents and then for twenty cents. Sadakat/Etfal had covered a wide area of subjects like mathematics, history, physics, religious information, geography and introducing animals. Also with the texts, some national and universal values were introduced to children and gave educational support to them. Having been the the first illustrated kid's journal, it had been taken as a leading example for the future kids journals and magazines published soon after.

Key Words: Sadâkat, Etfâl, kids journal, illustration

\section{GíRiş}

Çocuk gazeteleri ve dergileri, çocukların gelişim ve eğitim düzeylerine uygun olarak düzenlenen, farklı türlerde metinler içeren ve çeşitli görsel imgelerle desteklenen eğitim araçlarıdır. Ciravoğlu'na göre ise bu tanım: "Çocukların eğitim, bilim, bilgi ve görgülerini, genel kültürlerini, toplumsal olarak meydana gelen kimi olayları, çevre sorunlarını ele alan, çocuklara bilinç aşılayan süreli yayınlar" (1999: 183) şeklindedir. Bu gazete ve dergiler, çocukların hoşça vakit geçirmelerini sağlamanın yanı sıra onları çeşitli unsurlar bakımından destekler, yeni şeyler öğretir. Demiray (1973: 45), çocuk gazetelerinin zevkli ve eğlendirici yazılarıyla çocuklarda ilgi uyandırdığını söylerken bu eserlerin onlara edebiyat zevki ve sanat kültürü de kazandıracağını belirtir. Bununla birlikte çocuk gazete ve dergileri; okuma alışkanlığı kazandırmak, kelime dağarcığını zenginleştirmek, düşünme ve yorum yapma yetisini geliştirmek ve hayatı tanımak gibi pek çok konuda çocuğu destekler. Belirli dönemlerde çıkarılan bu süreli yayınları takip eden çocuk da bir sonraki sayıyı ilgi ve merakla bekleyecektir.

Ülkemizde süreli yayınların ortaya çıkışının, Tanzimat ile beraber başlayan Batılılaşma çabalarının göstergelerinden biri olduğu söylenebilir. Çocuklar için özel olarak çıkarılan gazete ve dergilerin basımı da bu sürecin devamına rastlar. İlk çocuk gazetesi kabul edilen Mümeyyiz (1869)'i diğer yayınlar izlemiş ve bu eserler dönemin çocuklarının gelişiminine katkı sağlamıştır.

Eski harfli çocuk gazete ve dergileri son yıllarda yazılan araştırma makaleleri ve lisansüstü tezler ile gün ışığına çıkarılmaya çalışılmaktadır. Balcı (2012: 203) da çalışmasında, bu gazete ve dergiler üzerine yapılan araştırmaların çocuk edebiyatı alanında sıkça rastlanan konu başlıklarından olduğunu belirtmiştir. Yapılacak araştırmaların çocuk 
edebiyatı sahasında oluşturulmuş edebi malzemenin de ortaya çıkmasına katkı sağlayacağını dile getirmiştir. Özdemir (2005:118) ise çalışmasında yer alan " 1869 'da yayınlanan Mümeyyizle başlayan ve 1928'e kadar çıkmaya devam eden, içlerinde büyük zenginlikler saklayan eski harfli binlerce çocuk dergisi ${ }^{1}$, yeni harflere kazandırılmalı" şeklindeki önerisiyle konunun önemini vurgular.

$\mathrm{Bu}$ çalışmayla daha önce yükssek lisans tezi olarak hazırlanıp günümüz alfabesine de aktarılan Sadâkat/Etfâl (1875) tanıtılmış; hakkında diğer kaynaklarda rastlanan hatalı bilgiler düzeltilmiş ve eksiklikler de giderilmiştir. Ayrıca resimli ilk çocuk gazetesi/dergisi kabul edilen Etfâl'de yer alan resimlerden örnekler sunulmuştur. Gazetenin tam koleksiyonuna, Hakkı Tarık Us Kütüphanesi Kataloğu sayfa 119' da yer alan “1075 Etfâl. HD1 Sıra No: 0540 / HTU Eski No: 76 (1-6 Sadâkat, 7-23 Etfâl)" bilgileri dikkate alınarak Beyazıt Devlet Kütüphanesi, Hakkı Tarık Us Bölümü'nden ulaşılmıştır.

\section{SADÂKAT / ETFÂL}

Sadâkat/Etfâl, 1875 yılında yayımlanır. Dönemin siyasi Sadâkat gazetesi tarafından çocuklar için özel olarak çıkarılmıştır. Ertuğ (1970: 228-229) ve İnuğur (2005: 249)'un eserlerinde açıkça belirtildiği üzere siyasi gazete olan Sadâkat, 1875 yılında Mehmet Efendi tarafından çıkarılmıştır. Günlük bir gazetedir ve İslâmî nitelik taşımaktadır. Yazarlar gazetenin çocuklar için de ayrıca bir yayın yaptığından ve bu yayının büyük ilgi gördüğünden bahseder. Yine Emiroğlu (1992: 19)'nun çalışmasında "Sadâkat de Mümeyyiz gibi siyasî bir gazetenin aynı adla çocuklar için çıkardığı bir ektir" bilgisine ulaşılabilir.

Bazı kaynaklarda Etfâl'in Sadâkat'ten ayrı bir gazete olarak değerlendirilebileceği söylenmiştir: “Türk Çocuk Edebiyatı'nda ikinci çocuk gazetesiyse 1875 yılında yayımlanan "Sadâkat" adlı haftalık bir gazetedir. Ancak "Sadâkat" adının çocukların pek ilgilerini çekmeyeceğini düşünen gazete sahipleri altıncı sayıdan sonra "Etfâl" adıyla yeni bir çocuk gazetesi çıkarmışlardır. Bilim ve fen konularında hem eğlendirici hem de bol resimli yazılara yer veren bu gazete bu alanda üçüncü bir çocuk gazetesi de sayılabilir” (Kıbrıs 2002: 300). Ancak gazetenin ilerleyen sayılarında, önceki sayılardaki metinlerin devamının, soruların cevaplarının yer alması ve en önemlisi Etfâl adını alan

1 Mehmet Özdemir'in cümlesinde geçen "binlerce çocuk dergisi" ifadesinin abartılı olduğu söylenebilir. Zira İsmet Kür, dergi sayısını 28 (1991: 557,558) olarak belirlerken Cüneyd Okay bu sayının 50 (1999: 216-217) olduğunu ifade eder. 
gazetenin ilk sayısının "Numara 7" ifadesi ile başlaması göz önüne alındığında onu ayrı bir gazete olarak kabul etmek doğru olmayacaktır.

Sadâkat/Etfâl'in imtiyaz sahibi olarak "Tahsin" ismi geçmektedir ancak tam olarak kimliği tespit edilememiştir.

Gazetenin yayın yeri İstanbul'dur. 11 Nisan 1291/ 15 Rebiyülevvel 1292 (23 Nisan 1875) Cuma günü ilk sayısı Sadâkat adıyla yayımlanan gazetenin "Mukaddime"si şu satırlarla başlar:

"Çocuklar! Hükümet-i Seniyye'den "Sadâkat" ismiyle bir gazetenin neşrine müsaade aldık. Gazete denilen şey her türlü havadisle ahlaka, edebe, sanata, ticarete dair güzel güzel sözleri yazıp halka bildirici bir vasitadır. Fakat öyle her şeyden bahseden gazetelerde çocukların anlayamayacağl ve anlasa da kendilerince bir fayda hâsıl etmeyecek şeyler yazılacağından öyle büyük gazetelerden çocuklar doğrudan doğruya fayda görmezler” (S.1, s.1).

Böylelikle ilk sayının giriş bölümünde gazetenin ne olduğu üzerinde durularak büyükler için yazılan gazetelerden çocukların doğrudan faydalanamayacağı dile getirilmiştir. Yazının devamında çocukların okuyup yazmasının vatanın geleceği için oldukça gerekli olduğu üzerinde durulmuş onlar için ayrı bir gazete çıkarmayı düşündükleri belirtilmiştir. Bu amaçla gerekli izni aldıkları söylenir.

Yine mukaddimenin son paragrafinda;

“Çünkü vatanın istikbalini te'min etmek istikbalde iş başına geçecek olanları şimdiden hazırlamak icap eder ki istikbalde iş başına geçecek olanlar bugün çocuk bulunanlardır. İste bu efkâra mebni biz de bu gazeteyi neşre başladık. Alıp okumak lazım ve fiyatı on para olduğu için zengin çocuklar birkaç tane alıp fakir olan arkadaşlarına hediye etmek lazımdır ki o çocuk borcu olan vatan hizmetini şimdiden böylelikle ödemiş olsun.” (S.1, s.1)

satırlarıyla zengin çocukların gazeteden birkaç tane alarak maddî durumu iyi olmayan arkadaşlarına armağan etmesi istenmiştir. Böylelikle çocuklar arasında hediyeleşme ve yardımlaşma duygularını geliştirmek ve diğer taraftan da daha çok çocuğa ulaşmak hedeflenmiştir.

Dönemin çocukları tarafından büyük ilgi gördüğü anlaşılan gazetenin "ilk sayısının 3000 nüsha kadar basıldığı" (Ertuğ 1970: 229; Topuz 2003: 403) ve bu sayının zamanın ölçülerine göre bir rekor olduğu söylenir. Selim Nüzhet (1931: 69-70) de çalışmasında elinde gazetenin 
ilk sayısının üçüncü basımı bulunduğunu belirtir. Bu hususu, gazetenin çok rağbet görmesiyle açıklar. Ancak gazete tümüyle okunduğunda üç bin sayısını doğrulayacak bir ifadeye rastlanmamıştır. 2. sayısına çocuklardan gördüğü ilgiye teşekkür ile başlayan gazete, birinci nüshanın daha çıktığı gün bin beş yüz adet sattığından bahseder. Ertesi gün gelen yoğun talep üzerine bin nüsha daha basıldığını ve onların da tükendiği dile getirir. Bu durumda gazetenin ilk sayısının iki bin beş yüz nüsha kadar sattığı söylenebilir.

İlk adı Sadâkat olan gazetenin 6. sayısında verilen bir ihtarla isminin değişeceği okuyuculara duyurulur:

"Efendiler! (Etfâl) namıyla bu kere ayrıca bir gazete ruhsatnamesi istihsal eyledim size dair yazacağım şeyleri bundan böyle o gazete ile neşredeceğim ve gelecek haftadan itibaren inşallah mezkûr gazetenin ihracına bed edeceğim."(S.6, s.1).

İhtarla verilen müjdeye uygun olarak gazetenin ertesi hafta "Etfâl" adını alıp yayın hayatına devam ettiği görülür. Bu sayıda gazetenin isim değişikliğine gitmesi "Sadâkat'in etfal tarafindan gördüğ̈̈ rağbet mucib$i$ teşekkür olduğundan ism-i müsemmasina mutabakat etmek ve hal ve şan-ı etfale layık olduğunu göstermek ve bazı mevâni-i mahûfeden halas olmak için" ifadesiyle açıklanır. Anlaşıldığı üzere bu değişiklik çocuklara yakışan bir isim bulmak ve siyasi tehlikelerden gazeteyi korumak çabasından ortaya çıkmıştır. Emiroğlu da çalışmasında isim değişikliğinin sebebini siyasi gelişmelere bağlar ve bunu "Siyasi gazete olan Sadâkat'in hükümet tarafından kapatılması tehlikesine karşı çocuklar için çıkarılan Etfâl bu şekilde bir olumsuzluktan da etkilenmeyecektir" (1992: 23) şeklinde dile getirir.

Gazete, "çocuklar" anlamına gelen "Etfâl" adıyla 17 sayı daha çıkmıştır. Toplamda 23 sayıya ulaşan gazete için, önceki kaynaklarda verilen sayı bilgilerinin hatalı olduğu söylenmelidir. Bu hatalı sayılar ise: "Sadâkat, altı hafta sonra ad değiştirerek Etfâl (Çocuklar) adıyla çıkar ve her iki adla toplam 13 sayıya ulaşır" (Şimşek 2002: 265); "Sadâkat'le benzer bir yayın politikası takip eden Etfâl'de Sadâkat'te var olan köşeleri görmek mümkündür ve kendisini ondan ayıran bir tarafı yoktur. Onaltı sayı yayınlanmıştır. (Toplam sayı Sadâkat'le beraber 6+16=22'dir)" (Okay 1999: 42); "Tahsin Beyin haftalık olarak, 28x30 $\mathrm{cm}$. boyutlarında çıkardığı ve dili biraz ağır olan Etfâl Dergisi 13 sayı yayımlanmıştır" (Yalçın-Aytaş 2003: 238) şeklindedir.

Sadâkat/Etfâl'in ilk sayısı, 11 Nisan 1291/15 Rebiyülevvel 1292 (23 Nisan 1875) tarihini taşır. Etfâl adının yer aldığı ilk sayı yani 
gazetenin 7. sayıs1 ise 23 Mayıs 1291/ 30 Rebiyülevvel 1292 (4 Haziran 1875) tarihlidir. Haftada bir çıkarılan bu gazetenin son basılan sayısı olan 23. sayının tarihi ise 6 [12] Eylül $1291^{2} / 24$ Şaban 1292 (24 Eylül 1875)'dir. Gazetenin 23 sayı olduğunu göstermek adına bu sayının ilk sayfası aşağıda verilmiştir:

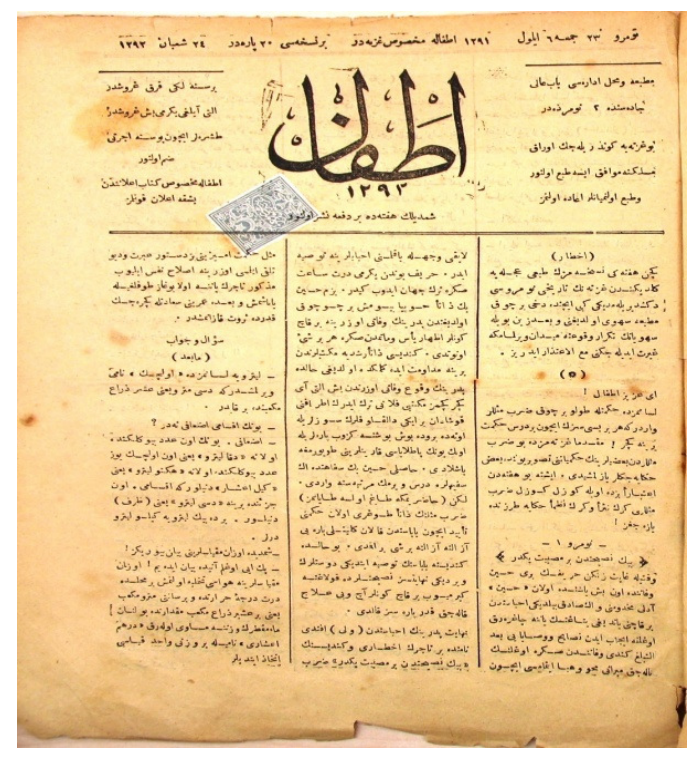

Etfâl, 23. say1

Cuma günleri çıkarılan gazetenin dört sayısının (3., 4., 5. ve 6. sayılar) pazar günü çıkarıldığı tespit edilmiştir. Sadâkat/Etfâl'in 2. sayısında bir "İhtar" ile yayın gününün değiştirileceği okuyuculara duyurulmuştur: “

Cuma günleri için büyük gazetemizin çıkarılması pek lazım olduğundan ve bir günde iki gazete çıkarllamayacağından size mahsus olan bu gazeteyi bundan böyle pazar günleri çıkaracă̆ımızı ihtar ederiz" (S.2, s.1).

$\mathrm{Bu}$ değişiklik dört hafta kadar devam etmiştir. Gazete, 7. sayıdan itibaren yani "Etfâl" ile birlikte yine cuma günleri yayımlanmıştır.

Haftalık bir gazete olan Sadâkat/Etfâl'in kapak sayfalarında Rumi ve Hicri olmak üzere iki farklı tarih bulunur. Gazetede birkaç yerde tarih

26 Eylül 1291 tarihinde gün hatalıdır. Çalışmanın ilerleyen kısımlarında bu durum açıklanmıştır. Doğru tarih “[12]”, şeklinde verilmiştir. 
hatası yapılmıştır. Bu hatalar şu şekilde sıralanabilir: 13. ve 14. sayıların Hicri tarihleri aynı; ikisi de "13 Cemaziyülahir 1292" şeklinde verilmiştir. 22. sayının tarihi 21. sayı ile aynı basılmıştır. Ancak 23. sayıda bir "Ihtar" yayımlayan gazete şu ifadelerle hatayı düzeltir:

"Geçen haftaki nüshamızın tabı aceleye geldiğinden gazetenin tarihini numarası değiştirilmediği gibi içinde dahi birçok matbaa sehvi olduğunu ve badezin böyle sehviyatın tekrar vukuuna meydan verilmemeye gayret edileceğini ma'a'l-itizar ederiz"' (S.23, s.1)

Yine 23. sayıda da Rumi tarih yanlış verilmiş̧tir.

Gazetenin basım tarihlerine Tablo 1'de değinilmiş, tespit edilen hatalı tarihler tablo üzerinde "[ ]" işaretinin içine doğru tarih yazılmak suretiyle tarafımızdan düzeltilmiştir. Rumi tarihler ve yayın gününün kesinliği göz önünde bulundurularak tabloya Miladi tarihler de eklenmiștir:

\section{Tablo 1: Sadâkat/Etfâl'in Basım Tarihleri}

\begin{tabular}{|c|c|c|c|c|}
\hline Sayı & Rumî & Hicrî & Miladî & Gün \\
\hline 1 & 11 Nisan 1291 & 15 Rebiyülevvel 1292 & 23 Nisan 1875 & Cuma \\
\hline 2 & 18 Nisan 1291 & 23 Rebiyülevvel 1292 & 30 Nisan 1875 & Cuma \\
\hline 3 & 27 Nisan 1291 & 2 Rebiyülahir 1292 & 9 Mayıs 1875 & Pazar \\
\hline 4 & 4 Mayıs 1291 & 11 Rebiyülahir 1292 & 16 Mayıs 1875 & Pazar \\
\hline 5 & 11 Mayıs 1291 & 18 Rebiyülahir 1292 & 23 Mayıs 1875 & Pazar \\
\hline 6 & 18 Mayıs 1291 & 25 Rebiyülahir 1292 & 30 Mayıs 1875 & Pazar \\
\hline 7 & 23 Mayıs 1291 & 30 Rebiyülahir 1292 & 4 Haziran 1875 & Cuma \\
\hline 8 & 30 Mayıs 1291 & 7 Cemaziyülevvel 1292 & 11 Haziran 1875 & Cuma \\
\hline 9 & 6 Haziran 1291 & 14 Cemaziyülevvel 1292 & 18 Haziran 1875 & Cuma \\
\hline 10 & 13 Haziran 1291 & 21 Cemaziyülevvel 1292 & 25 Haziran 1875 & Cuma \\
\hline 11 & 20 Haziran 1291 & 28 Cemaziyülevvel 1292 & 2 Temmuz 1875 & Cuma \\
\hline 12 & 27 Haziran 1291 & 6 Cemaziyülahir 1292 & 9 Temmuz 1875 & Cuma \\
\hline 13 & 4 Temmuz 1291 & 13 Cemaziyülahir 1292 & 16 Temmuz 1875 & Cuma \\
\hline 14 & 11 Temmuz 1291 & 13 [20] Cemaziyülahir 1292 & 23 Temmuz 1875 & Cuma \\
\hline 15 & 18 Temmuz 1291 & 27 Cemaziyülahir 1292 & 30 Temmuz 1875 & Cuma \\
\hline 16 & 25 Temmuz 1291 & 5 Recep 1292 & 6 Ağustos 1875 & Cuma \\
\hline 17 & 1 Ağustos 1291 & 12 Recep 1292 & 13 Ağustos 1875 & Cuma \\
\hline 18 & 8 Ağustos 1291 & 19 Recep 1292 & 20 Ağustos 1875 & Cuma \\
\hline 19 & 15 Ağustos 1291 & 26 Recep 1292 & 27 Ağustos 1875 & Cuma \\
\hline
\end{tabular}




$\begin{array}{lllll}20 & \text { 22 Ağustos 1291 } & \text { 3 Şaban 1292 } & \text { 3 Eylül 1875 } & \text { Cuma } \\ 21 & \text { 29 Ağustos 1291 } & \text { 9 Şaban 1292 } & \text { 10 Eylül 1875 } & \text { Cuma } \\ 22 & \begin{array}{l}\text { 29 Ağustos [5 Eylül] } \\ \text { 1291 }\end{array} & 9 \text { [16] Şaban 1292 } & \text { 17 Eylül 1875 } & \text { Cuma } \\ 23 & 6[12] \text { Eylül 1291 } & \text { 24 Şaban 1292 } & \text { 24 Eylül 1875 } & \text { Cuma }\end{array}$

Gazetenin 7. sayısında "M.R" rumuzuyla yazılmış bir yazı bulunmaktadır. “...Sadâkat'in altı nüshasını yazdı̆̆ım misilli işbu \{Etfâl\} gazetesini dahi fahri olarak tahrir edeceğimi...” (S.7, s.2) ifadesinin açıkça yer aldığı bu yazıdan anlaşılacağı gibi gazetenin yazarı M.R'dir.

M.R bu yazısında, Sadâkat/Etfâl'in imtiyaz sahibi Tahsin ile eskiden tanıştığını dile getirmiştir. Farklı bir sayıda tekrarına ya da açılımına rastlanmayan bu rumuzun sahibi tespit edilememiştir.

Gazetenin okuyucu yazılarına açık olduğu; ancak gönderilen her evrakın basılmayacağı, basılması için belli kriterler taşıması gerektiği " $B u$ gazeteye gönderilecek evrak mesleğine muvafik ise tab olunur ve tab olunmayanlar iade edilmez" ifadesiyle okuyuculara duyurulur.

Sadâkat/Etfâl'in tek yazarı olarak nitelendirebileceğimiz M.R dışında, gazetede birkaç yazısına yer verilmiş bir öğrenci bulunmaktadır. İlk olarak gazetenin 19. sayısında gönderdiği mektubun basımı yer alan bu öğrencinin adı açıkça belirtilmeyip “A.Y” şeklinde yazılmıştır. Öğrenci hakkında ulaşılabilen tek bilgi ise Mahrec-i Aklam ikinci sene şakirdanından olduğudur. A.Y mektubunda, izin verilirse gazeteye "Tarih" bilimine dair bir şeyler yazmak istediğini ifade etmiştir. Mektubun altına gazete tarafından bir not düşülmüş, isteğinin memnuniyetle yerine getirileceği bildirilmiştir. İki hafta sonra yayımlanan sayıda "A. Y" imzalı "Bir Hoca ile Şakirdanın Muhaveresi" isimli yazı yer alır. Ertesi iki hafta yazının devamı yayımlanmıştır. Son sayıda diğer metinler gibi bu yazı da "Mabadı var" ifadesiyle son bulmuştur. Bir öğrencinin yazılarına tefrika halinde yer vermesi Sadâkat/Etfâl'in çocuklara verdiği değerin göstergesi olarak nitelendirilebilir.

Sadâkat/Etfâl'de ayrıca dönemin diğer gazetelerinden olan "Kırkambar" (S.12, s.1) ve "Zaman" (S.14, s.3) dan alınan birer metne de yer verilmiştir.

Gazetenin başlık kısmında "Etfâle mahsus kitap ilanından başka ilan konulmaz" şeklinde bir açıklama yer alır ve 2. sayıdan itibaren de 
ilanlar verilir. 6., 7. ve 8. sayılarda hiçbir ilana rastlanmazken geri kalan bütün sayıların son sayfalarında bu bölüm bulunur. Gazetede üç farklı ilan tespit edilmiştir. Bunlardan ikisi kitap tanıtır, diğeri ise çocuklara gazetenin bütün nüshalarının yanı sıra kâğıt da bulabilecekleri bir dükkânı tarif eder. En sık tekrarlanan ilan bir İlmihâl kitabı tanıtımıdır:

"Dinimizin her bir ahvalini ve bize lazım olan şeyleri bildiren kitapların en güzeli Beyazıt'ta yetmiş bir numaralı mücellid Osman Efendi'nin dükkânında satılan "İlmihâl" kitabıdır. Bu kitabın ifadesi gayet açı ve cümlenizin anlayabileceği surette olmakla beraber fiyatı da üç kuruş olduğundan her çocuğun bir tane edinmesi lazımdır."

Yine çocukların hem dil öğrenebilecekleri hem de güzel ahlak edinebilecekleri önerisiyle, tercüme bir kitap sıkça tanıtılmıştır: "Efendiler Hindistan ulemasindan olup el-yevm İstanbul'da arzu edenlere her şeyden ders okutmakta olan seyyah-l meşhur faziletli İskender Efendi (Emsalü'l Lokman fì Tehzibi'l Ezhân) namıyla size yarar ve sizin ahlakınıza hizmet eder bir kitap tercüme ve neşretti bu kitap dört lisan üzeredir yani Türkçe Arapça Farisice Fransızcadır bundan hem lisan ögrrenirsiniz hem de ahlak tezyin ve terbiye edecek hikâyeler meseller bellersiniz fiyatı da ucuzcadır her kitap satılan yerlerde bulabilirsiniz". Çocuklara mahsus olarak çıkarılan bu gazetenin, onlar için uygun olabilecek kitapların ilanından başka ilanlara yer vermeyişi özellikle dikkate değer bir husustur. Bu durum, Sadâkat/Etfâl'in maddî kaygılardan uzak ve önceliği çocukların eğitimi olan bir gazete olarak düşünülmesine yol açar.

\section{Şekil Özellikleri}

Gazetenin adı, ilk sayfanın üst-orta kısmında verilmiştir. İsmin hemen üstünde ise "Etfâle mahsus gazetedir" ifadesi yer alır. Bu açıklama hedef kitlenin çocuklar olduğunu belirtmenin yanı sıra Sadâkat/Etfâl'in kendini "gazete" olarak nitelendirdiğinin de göstergesidir. Yine gazetenin sayı numarası, tarihler ve fiyatı üst kısımda belirtilmiştir.

Yapılan araştırmada "Sadâkat'in 1.sayısı sarı, 2. sayısı pembe ve diğer sayılar "Etfâl" ile birlikte sarı kağıda" (Duman 2000/2: 723) basıldığı bilgisine ulaşılmıştır. Ancak incelenen nüshada durum farklıdır. Sadâkat'in ilk iki sayısı sarı geri kalan bütün sayılar, Etfâl adı ile olanlar dâhil, pembe kâğıda basılmıştır. 


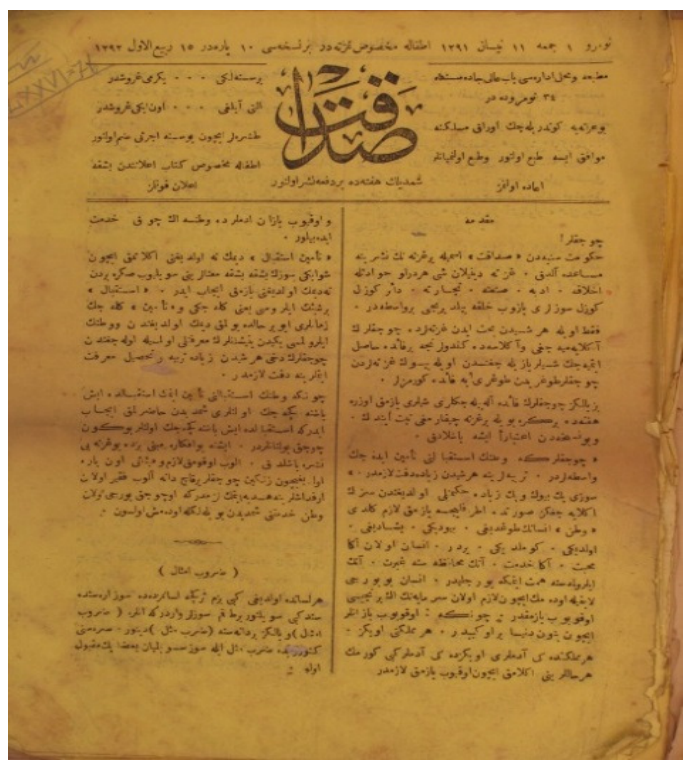

Sadâkat, 1. say1

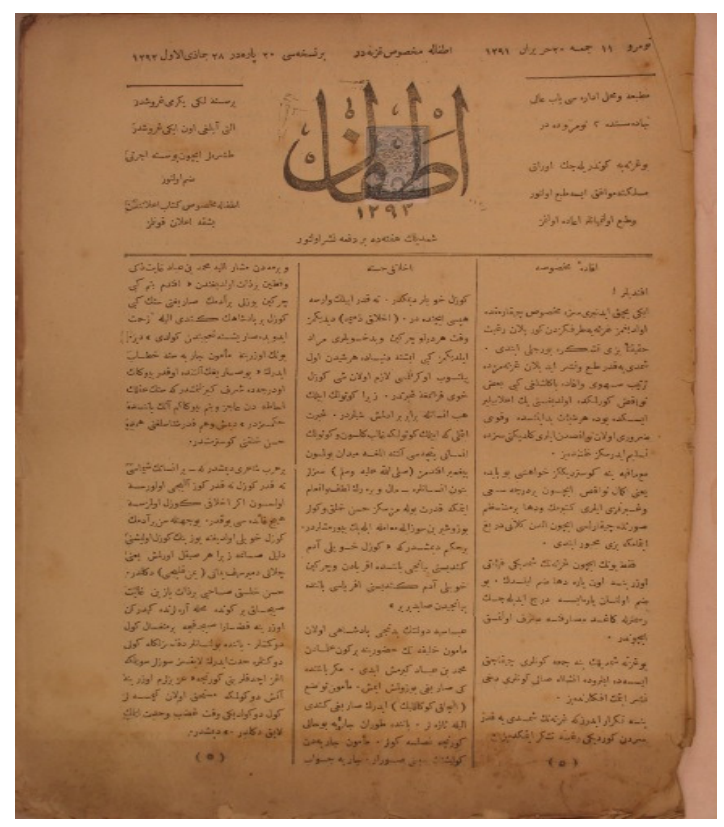

Etfâl, 11. say1 


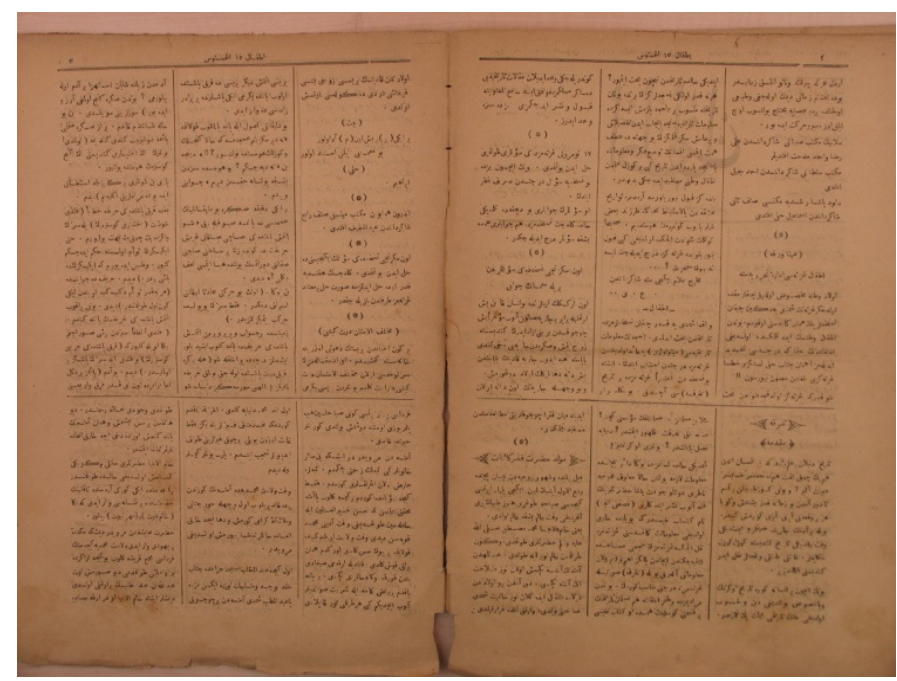

Etfâl, 19.say1, 2. ve 3. sayfalar

Sadâkat'in 1-6. sayılar ve Etfâl'in 7-10. sayılarının boyutları $24 \times 30,5 \mathrm{~cm}$ iken 11. sayıdan itibaren boyutlar $24 \times 34 \mathrm{~cm}$. şeklinde değişmiştir (Duman 2000/1: 288). Bu değişiklik ile beraber gazetenin sütun sayısının ve fiyatının da arttığı tespit edilmiştir. İlk on sayının bir nüshası 10 paraya satılırken 11 . sayıdan itibaren 10 para daha zam yapıldığı duyurulmuştur. Zira bundan sonraki sayılarda resimler basılacak ve bu resimler ile kâğıt masrafı artacaktır. Fiyatı 20 paraya yükselen gazetenin daha sonra ücreti değişmemiştir. Dönemin diğer gazete ve dergileri gibi bir çeşit abonelik uygulamasına giden Sadâkat/Etfâl'in altı aylık ya da bir senelik ücretleri şu şekildedir: İlk on sayıya kadar altı aylığ 12 kuruş, bir seneliği 20 kuruş; 11. sayıdan sonra altı aylığ 25 kuruş, bir seneliği 40 kuruş. Taşralar için posta ücretinin ekleneceği de ayrıca belirtilmiştir.

Gazete dört sayfadan yani iki yapraktan müteșekkil olup yukarıda da belirttiği gibi ayrı bir kapak sayfası oluşturma yoluna gidilmeyerek ilk sayfanın üst kısmı kapak bilgilerine ayrılmıştır. İlk on sayıda metinler iki sütun olarak düzenlenirken gazetenin 11. sayısından itibaren metinlerin üç sütunda verildiği görülür. Son beş sayıda (19., 20., 21., 22. ve 23. sayılar) ise üç sütunun yanı sıra ikinci ve üçüncü sayfalar ikiye bölünerek kullanılmıştır. Şekil özellikleri için verilen görseller sütun farklarını da ortaya koymaktadır. 
Sadâkat'te sayfa numarası bulunmaz. Gazete, Etfâl adını aldıktan sonra sayfalarını numaralandırmıştır. Numaralar, kapak bilgilerinin de bulunduğu ilk sayfalarda yer almazken diğer sayfalarda kimi zaman sağ üst kimi zaman da sol üst köşede bulunur. Makalede Sadâkat'in sayfaları da Etfâl'deki gibi numaralandırılmış ve örnekler bunun üzerinden verilmiştir. Bölünmüş sayfalar için ise üst kısımlara "a", alt kısımlara "b" harfi eklenerek ayrım sağlanmıştır.

Sadâkat/Etfâl ile ilgili yapılan araştırmalarda Pınarcı'nın "Çocuk Dergileri” (2013) başlıklı yazısında yanlış görselleri kullandığı tespit edilmiştir. Yazar, Etfâl'in ilk adı olan Sadâkat'i okuyucuya tanıtırken çocuklar için yayımlanan bu gazetenin yerine aynı kişi tarafından çıkarılan, siyasi, günlük bir gazete olan Sadâkat'in 2 Şubat 1877 tarihli 73. sayısının kapak fotoğrafını metne eklemiştir. Yine Sadâkat'in 6. sayısından sonra Etfâl adını aldığı bilgisi verilirken bu defa da söz konusu Etfâl'den sonraki yıllarda yayın hayatına başlayan, Doktor Memduh tarafından haftalık olarak çıkarılan aynı adlı gazetenin kapak fotoğrafı metne eklenmiştir. Makale ile bu yanlışlıkların düzeltilmesi de amaçlanmıştır.

\section{Dil, yazım ve noktalama:}

Hedef kitlesi çocuklar olan Sadâkat/Etfâl'de sade bir dil kullanılmıştır. Araştırmacılar da bu görüştedir: "Tahsin Beyin 1875 yılında çıkardığı Sadâkat Dergisi, Mümeyyiz Dergisinden daha sade bir dille yayınlanmıştır”" (Yalçın-Aytaş 2003: 238); “1286' da yayımlanmış ve sade dile özen göstermiş olan 'Mümeyyiz'inkinden de sadedir, kendinden sonrakilerin pek çoğundan da" (Kür 1991: 27). Ancak gazeteye bakıldığında Arapça, Farsça ve Fransızca kelimelerin varlığı da göz ardı edilemez. Buna rağmen dilimizin Türkçe olduğunu, "Bizim Türkçe lisanımızda", "Lisanımızı yani Türkçeyi" gibi ifadelerle sıkça dile getirmesi dikkat çekicidir.

Sadâkat/Etfâl'de "Durub-1 Emsal" başlıklı yazılarda Türkçenin doğru kullanılması ve atasözlerinin önemi üzerinde durulur. Birkaç tane atasözünün anlamı, çocukların ilgisini çekebilecek ve o atasözünü ezberletmekten ziyade gerçekten kavrayabilecekleri metinlerle açıklanır. Ayrıca gazetenin "Lisanımızı yani Türkçeyi gayet güzel söylemek isteyenlere o durub-ı emsali ezberletmek lazımdır. Hele insan çocukluktan böyle hikmetli söz söylemeye alışırsa büyüdüğ̈̈ zaman daima güzel güzel söz söyler" (S.1, s.2) gibi cümlelerle çocukları atasözü kullanmaya özendirdiği görülür. 
Gazetenin 2. sayının ilk yazısı olan "Kalfa" adlı metnin sonunda "Alt tarafi sonra" ve 6. sayıda yer alan "Bir Hoca ile Çalışkan Bir Mektep Çocuğu" başlıklı yazının sonunda "Alt tarafi var" ifadeleri yer alırken, daha sonraki sayılarda yazıların bitiminde "Mabadı var" ifadesinde karar kılındığı tespit edilmiştir. İlk sayılarda Türkçesi kullanılırken sonraki sayılarda "konunun devamı" anlamına gelen Arapça "mabad" kelimesinin tercih edilmesi düşündürücüdür.

Gazetede nokta, virgül, iki nokta, soru işareti, ünlem işareti, uzun çizgi, tırnak işareti, denden işareti, yay ayraç gibi noktalama işaretlerinin kullanıldığı görülür. Bu işaretlerin yanı sıra kimi yerlerde ardı ardına iki nokta "Aferin efendi! Memnun olduk dediğin gibi sehiv olmuş ne çare insan hatadan salim olamaz.." (S.5, s.4), dört nokta "Aferin matmazel cevabınız pek güzeldir siz de etfal-i nâsa numune gösterilecek hanımların ikincisi oldunuz. Çalış gayret et...." (S.5, s.3), iki veya üç ünlem "Ha!!! Bakın ben söyleyeyim!!” (S.3, s.1) ya da noktalama işaretlerinin bir arada olmas1 "Evladım niçin sen de kuşunu boğmadın?.." (S.17, s.1), "Bir de ertesi günü hocanın önüne geleyim ki bütün yaptığım dersler yanlış!...." (S.20, s.1) gibi kullanımların olduğu da saptanmıştır.

Yine cümlenin başında olup da sonunda olmayan veya sonunda olup da başında bulunmayan tırnak işaretleri mevcuttur: Ezmine-i kadime hikâyâtında arslanın Uluvv-i Cenabıhakk'ında mütalaa ettiğimiz rivayetlerden) Ader-i Kâis nâm esirin arslan hikâyesi pek garip olduğundan burada zikrini münasip gördük!" (S.5,s.1), "Efendiler!

Kimi yerlerde tırnak işareti içindeki cümlelerin sonunda herhangi bir noktalama işareti bulunmamaktadır: "Sen nasıl oldu da öyle güzel bir kayda tutuldun" (S.19, s.3b), "Benim ismim Matar yani yağmurdur" (S.20, s.2a).

Noktanın zaman zaman virgül yerine kullanıldı̆̆ 1 da dikkat çekmektedir: "Hükümet-i Seniyyeden "Sadâkat" ismiyle bir gazetenin neşrine müsaade aldık. Gazete denilen şey her türlü havadisle ahlaka. edebe. sanata. ticarete dair güzel güzel sözleri yazıp halka bildirici bir vasıtadır" (S.1, s.1). Bazı yerlerde de nokta, soru işareti görevi üstlenir: "Her birine kaçar yumurta düşer." (S.1, s.4).

Denden işaretine sadece 21. sayıda rastlanmıştır. Metrenin katları anlatılırken kullanılan bu işarete şu şekilde yer verilmiştir:

"Metrenin on cüzünde biri desimetre 
TÜBAR XXXVI.2014-Güz Arş.Gör.A NurERCAN Yrd.Doç.Dr. Şerife AKPINAR

“ yüz cüzünde biri santimetre

“ $\quad$ bin cüzünde biri milimetre

On metre yani on zirâ uzunluğa dekametre

Yüz “ “ yüz “ “ hektometre (...)” (S.21, s.2a).

Cümlelerin veya paragrafların sonunda hiçbir noktalama işaretinin bulunmadığı yerler de vardır. Ayrıca yeni cümleye geçiş, çoğu zaman paragraf haricinde- kelimeler arasında bırakılan boşluk artırılarak sağlanmıştır.

Gazetenin bazı yerlerinde harf eksikliğinden kaynaklanan yazım hataları mevcuttur. Bu hatalara şu örnekler verilebilir:

* "Hikâye" başlığı altındaki yazıda "emval" kelimesi yazılırken baştaki "elif harfi" eksiktir. (S.1, s.1)

* "Bir Küçük Hisse Alınacak Kıssa" başlıklı metinde "sualini" kelimesi yazılırken baştaki "sin harfi" eksiktir. (S.19, s.4)

* "Resmin Tarifi" başlığı altında balinaların çokça bulunduğu ülkeler anlatılırken "Japonya" yazılırken baştaki "je harfi" eksiktir. (S.23, s.3)

Gazete "Tashih" adı altında sonradan fark edilen bazı hatalı ifadeleri düzeltme yoluna gitmiştir. Düzeltmeler şu şekildedir: "(4) numaralı nüshamizın ikinci sayfasının ikinci sütununun on dokuzuncu satırında "hayvanları kedi cinsinden addederek "yazılacak iken "kedi" lafzı sehven "kendi" diye yazılmış ve o cihetle mana bozulacă̆ı aşikâr bulunmuş olduğundan tashihine lüzum gördük." (S.5, s.3) ve "Geçenki (5) numaralı nüshamızda on dördüncü cevabın ikinci satırında "biri (1) diğeri" yazılacak iken sehven "biri (11) diğeri” yazıldı̆̆ından tashih-i keyfiyete ibtidâr kılındı." (S.6, s.1)

Ayrıca Sadâkat/Etfâl'de “...kalemi alıp istediklerini doğru yazmaklı̆̆ isterim" (S.6, s.3), "Kâbe'ye gitmekliğin daha başka faziletleri de vardır" (S.8, s.1), "Senin daha sair yerler de vatanımdır demekliğinden Osmanl memleketlerinin hepsini bilmekliğin anlaşılır" (S.9, s.1) gibi kullanımlar mevcuttur. Yine gazetede yer alan "...bunları bir adam azdan az iki senede yapabileceği farz olunsa..." (S.3, s.2) ya da “...onuncu gün havada birçok kuşların uçuştuklarını görerek...” (S.20, s.3a) ve "O yerde birçok çocuklar kendi kendilerine oynamakla meşgul oldukları hâlde..." (S.1, s.3) şeklindeki örnekler Sadâkat/Etfâl'in dil kullanımına örnek olarak verilebilir. 


\section{Resimler:}

Resimler "görsel algıyı geliştiren birer uyaran olmanın yanında, çocukların anlama becerilerinin gelişmesinde de payı olan araçlardır" (Sever 2008: 178). Bu nedenle metinlerin resimlerle desteklenmesi kavramayı kolaylaştırır. Onlar "bazen sözcüklerin yerini tutarak, bazen yorumlama görevini yerine getirerek veya yapılacak işleri göstererek ilgili bulunduğu metni türlü yollardan açıklayabilirler" (Oğuzkan 2010: 373). Sayfalarında resimler olan bir gazete ya da dergi albenili olacak ve çocuklara daha cazip gelecektir. Kaplan, "1880 yıllarından sonra Türk dergilerinde görülmeğe başlayan resim ve fotoğraf, Türk kültür ve edebiyat tarihi bakımından önemli bir mânâ taşır. Türk okuyucusu Batıdan gelen resim ve fotoğraflarda sanata akseden gerçek hakkında canlı bir fikir edinir" (2007: 102) sözleriyle resimlerin okuyucu için yeni bir pencere açtığından bahseder. Bu alana öncülük eden bir yayın da Etfâl'dir.

Okay'ın çalışmasında 'Etfâl'i Sadâkat'ten ayıran herhangi bir farklı tarafı yoktur" (1998: 141) şeklinde bir tespit yer alır ancak Etfâl'in metinleri görsel unsurlarla zenginleştirmiş olması dikkate değer bir farktır. Ayrıca Etfâl (1875), resim yayımlayan ilk çocuk gazetesi/dergisi unvanına sahiptir (Şimşek 2001; Kasap 2011: 7; Şentürk 2011; Altay 2012; Er 2012). Karabıçak (2011)'ın çalışmasında çocuk gazetelerinde resim kullanımıyla ilgili yer alan "9 Kasım 1876'da yayınlanmaya başlayan Arkadaş gazetesinde resimler ilk defa kullanılmaya başlıyor" ifadesi de bu durumda düzeltilmeye muhtaçtır.

Etfâl'de on resim vardır. Gazetedeki ilk resim, 8. sayının üçüncü sayfasında yer alırken geri kalan tüm resimler sayıların son sayfalarında bulunmaktadır. Anlaşılır şekilde çizilen bu resimlerin gazeteye eklenmesiyle hem dikkat çekilmiş hem de çocuklar çeşitli konularda bilgilendirilmiştir. Altı resmin (8., 15., 20., 21., 22. ve 23. sayılarda) açıklamaları yayımlandıkları sayıda bulunur. Üç resmin (11., 16. ve 17. sayılarda) açıklamasının ise bir sonraki sayıda yer alacağı okuyucuya duyurulmuştur. Böylece çocukların resimle ilgili bir hafta boyunca düşünmeleri sağlanmış, ilgi ve merakları arttırılırken hayal güçlerini geliştirmeleri de amaçlanmıştır. Ancak bu resimlerden sadece birinin (Kedi-S.11) söylendiği gibi diğer sayıda açıklamasına rastlanır. Eldeki sayılarda diğer iki resme ait açıklama yer almamaktadır. Yine 12. sayıda altına "Yanar dă̆ resmidir" diye not düşülen resim hakkında da daha fazla açıklama yapılmamıştır. Gazetedeki resimlerin sıralaması Tablo 2'deki gibidir: 
Tablo 2: Etfâl'de Yer Alan Resimler

\begin{tabular}{|c|c|l|}
\hline Sayı & Sayfa & Resmin Açıklaması \\
\hline 8 & 3 & $\begin{array}{l}\text { (Boz) Tabir Olunan Hayvanın Tuzağa } \\
\text { Tutulması }\end{array}$ \\
\hline 11 & 4 & (Kedi) \\
\hline 12 & 4 & (Yanar Dağı Resmidir) \\
\hline 15 & 4 & Fecr-i Şimalî \\
\hline 16 & 4 & Bir Geyiğin Tuzağa Tutulması $^{3}$ \\
\hline 17 & 4 & [Ormandaki Hayvanlar] $^{3}$ \\
\hline 20 & 4 & Toprak! Toprak! \\
\hline 21 & 4 & 1680 Senesinde Tulu Eden Kuyruklu Yıldız \\
\hline 22 & 4 & Yıldırım Vurmuş Adam \\
\hline 23 & 4 & Balina Balığının Avlanması \\
\hline
\end{tabular}

Etfâl'de "İlm-i Hayvanat” başlığı ile farklı türlerden hayvanlar hakkında ayrıntılı bilgiler verilmektedir. 11. sayıya bir "kedi" resmi eklenmiş ve bir sonraki sayıda çocuklara bu kedi cinsi tanıtılmıştır:

"Bundan evvelki nüshamızda resmini derç etmiş olduğumuz kedi hakkında burada bazı malumat verelim.

Mezkûr kedi Avrupa ormanlarında vahşet yani yabanilik halinde yaşar bir nev kedilerdendir isterseniz resmine bir daha dikkat ediniz hani ya nevilerinin bir yolu siyah bir yolu ondan daha açıkça gibi görünür ya. Fakat o açıkça gibi görünen tüyler beyaz değil sincabî yani devetüyü rengindedir. Bunlar adeta her memlekette ve hatta bizim evlerde bulunan kedilerin cinsindendir. Bunların daha birçok nevileri vardır. Pençeleri biraz içeri doğru kıvrılmış tırnaklarla silahlanmıştır ki yiyecekleri şeyleri buna takarak ağızlarına götürürler. Gözlerinin bigi elif şeklinde olarak geceleri gündüz nasıl görürler ise öyle görürler” (S.12)

Gazetede yer alan resimlerden bir tanesi etrafındaki çerçeve şeklinde süslemesiyle diğerlerinden ayrılır. 12. sayıda bulunan bu çizimde, bir yanar dağın lav püskürtmesi ve ardından gökyüzünü

\footnotetext{
${ }^{3}$ Resme dair bir yazı bulunmamaktadır. İçeriğe göre tarafımızdan isimlendirilmiştir.
} 
kaplayan dumanlar resmedilmiştir. Çizimin altına "Yanar dă̆ı resmidir" notu vardır. Bunun dışında resimle ilgili ayrıntılı bilgi verilmemiştir.

Etfâl'in son sayısı olan 23. sayının son sayfasında yine bir resim bulunur. Altına "Balina balığının avlanması" şeklinde not düşülen resmin açıklaması yine aynı sayıda "Resmin Tarifi" başlığı altında aşağıdaki cümlelerle başlar:

"Dördüncü sayfada resmi derç edilen balı̆̆a (balina) balı̆̆ı denilir. Bunun evi -ki bugünkü günde ekseriya (bahrının) ve (İskoçka) ve (kutb-ı cenubî) veya Japonya adasinın şimal taraflarını ihata eden denizlerde icra edilir-gayet de kârlı bir av olduğundan her sene mahsusen birçok gemilerle zikrettiğimiz denizlere birçok adamlar gider. Bununla beraber insan bu avda ya fevkalade bir ticarete nail yahut da pek büyük tehlikelere duçar olur(...)" (S. 23)

\section{Muhteva Özellikleri}

Birbirinden farklı konularla çocukların ilgisini çekmenin yanı sıra onları bilgilendirmeyi de amaçlayan gazete, eğlendirirken öğretmektedir. Bu gaye ile, Sadâkat/Etfâl'de okuyuculara matematikten tarihe, fizikten coğrafyaya, İslamiyet ile ilgili konulardan hayvan tanıtımlarına kadar uzanan geniş bir yelpaze sunulmuştur. Yalın bir dil ve basit örnekler ile konular anlatılmıştır. Bazı atasözlerinin açıklamaları, Allah'ın büyüklügünü anlatan hikmetler, latifeler de gazetede yer verilen yazılar arasındadır. Sadâkat/Etfâl'de kurgu metinlerin yanı sıra Amerika'nın keşfi gibi gerçek yaşamdan alıntılar da bulunur.

Gazetede ağırlıklı olarak matematik soruları olmak üzere toplam doksan bir -biri öğrencinin gönderdiği- soru bulunmaktadır. 6. sayıda Darülmaarif öğrencilerinden Süleyman'ın coğrafya ile ilgili gönderdiği bir soruya yer verilmiştir. Üç sayıda (11., 19. ve 23. sayılar) herhangi bir soruya rastlanmamıştır. Gerekçe olarak önceki soruların cevabının gelmediği söylenmiştir. 19. sayıda yer verilen bir ihtarla bu sayıdan sonra soruların iki kısma ayrılacağı belirtilir. Bunların birisinin Rüşdiye diğerinin Sultanî talebeleri için olacağı ifade edilmiştir ve bir sonraki sayıdan itibaren soruların denildiği gibi iki kısma ayrıldığı görülür. Sadâkat/Etfâl, çocuklarının bu sorulara olan ilgisini artırmak ve cevap gönderme davranışlarını pekiştirmek için sorulara doğru cevap veren ilk çocuğa yaldızlı gazete verirken ikinci ve üçüncüye de birer gazete hediye 
etme yoluna gitmiştir. Sadâkat/Etfâl'de yer alan soruların konulara göre dağılımı Tablo 3'tedir:

Tablo 3: Sadâkat/Etfâl'deki Soruların Konulara Göre Dağılımı

\begin{tabular}{|c|c|c|c|c|c|}
\hline Sayı & Coğrafya & Din Kültürï̈ & Matematik & Mantık & Toplam \\
\hline 1 & 1 & 1 & 1 & 1 & 4 \\
\hline 2 & 1 & 2 & 1 & & 4 \\
\hline 3 & & 1 & 3 & & 4 \\
\hline 4 & & & 4 & & 4 \\
\hline 5 & & & 4 & & 4 \\
\hline 6 & 1 & & 5 & & 6 \\
\hline 7 & & 1 & 4 & & 5 \\
\hline 8 & & 1 & 4 & & 5 \\
\hline 9 & & & 4 & & 4 \\
\hline 10 & & & 5 & & 5 \\
\hline 11 & & & & & 0 \\
\hline 12 & 1 & & 5 & & 6 \\
\hline 13 & & & 5 & & 5 \\
\hline 14 & & & 5 & & 5 \\
\hline 15 & & & 4 & & 4 \\
\hline 16 & & & 3 & & 3 \\
\hline 17 & 1 & & 3 & & 4 \\
\hline 18 & & 1 & & 1 & 2 \\
\hline 19 & & & & & 0 \\
\hline 20 & 1 & 1 & 5 & & 7 \\
\hline 21 & & & 4 & & 4 \\
\hline 22 & 2 & & 4 & & 6 \\
\hline 23 & & & & & 0 \\
\hline Toplam & 8 & 8 & 73 & 2 & 91 \\
\hline
\end{tabular}

Tablo 3 incelendiğinde, matematik ile ilgili yetmiş üç, coğrafya ve din kültürü ile ilgili sekizer ve mantık konusu dâhilinde değerlendirebilecek iki soru olduğu görülmektedir. Gazetenin 7. sayıs1 -7 soru ile- en fazla soruya sahip olanıdır. Hiçbir sorunun yer almadığı üç sayı göz ardı edilince en az soru içeren -2 soru ile- 18. sayıdır.

Gazete bazı sayılarında okuyuculardan gelen mektuplara yer vermiştir. Şüphesiz ki bu, mektuplarını basılmış halde gören çocukların 
gazeteye olan ilgisini artırmıştır. Ayrıca hemen hemen her sayıda, soruların doğru cevaplarını gönderen öğrencilerin isimleri ve okulları ilan edilmiştir. Yine bu uygulamanın da çocuklar için övünç kaynağı olduğu düşünülebilir.

Sadâkat/Etfâl'de, 4. sayıdan itibaren "İlm-i Hayvanat" başlı̆ğ ile bazı hayvanların tanıtımı yapılmıştır. Bu yazılar ansiklopedik niteliktedir. Yazılarda, bahsi geçen hayvanların fiziksel özellikleri, nerelerde yaşadıkları, ne ile ve nasıl beslendikleri, nasıl çoğaldıkları ve avlandıkları vb. hususlar üzerinde durulmuştur. Kimi yerde metinler resimlerle de zenginleştirilerek çocuğun anlatılanları daha rahat kavrayabilmesi sağlanmıştır. Oğuzkan'ın (2010: 373) da belirttiği gibi "Bir çocuğa uzun uzun bir zürafayı, aslanı veya kartalı anlatmak yerine bu hayvanların iyi yapılmış resimlerini göstermek şüphesiz daha doğru olur”. Çoğunluğu vahşi hayvanların tanıtımından oluşan bu yazılardaki söz konusu hayvanlar Tablo 4'te verilir:

\section{Tablo 4: Sadâkat/Etfâl'de Tanıtılan Hayvanlar}

\begin{tabular}{|c|l|}
\hline Sayı & Hayvanlar \\
\hline $4-5$ & Arslan \\
\hline 8 & $\begin{array}{l}\text { Kaplan-Pars } \\
\text { Jagar-Amerika Pelengi } \\
\text { Boz }\end{array}$ \\
\hline 10 & Ay1 \\
\hline 12 & Kedi \\
\hline 23 & Balina \\
\hline
\end{tabular}

Sadâkat/Etfâl ayrıca, okuma yazmanın, okula devamın, çalışkan ve terbiyeli olmanın önemini sık sik vurgulamış; çocukların eğitimi konusunda yardımcı olabilecek metinler yayımlamaya özen göstermiştir. Bunların yanı sıra okul derslerine katkı sağlayabilmek için sorular sorulmuş, konular anlatılmıştır. Harita bilgisi, zaman kavramı, sayıların tanıtımı, dünyanın hareketleri, uzunluk ölçüleri, yıldırım, elektrik, kuyruklu yıldızlar gazetenin ayrıntılı açıklamalarla yer verdiği konulardandır. Sadâkat/Etfâl'de 2. sayıdan itibaren ara ara "Kalfa" başlığı altında yazarın belli bir sıralama yaparak okuyucuya sunduğu dersler de bulunmaktadır. Gazeteyi takip eden çocukların bu yazılarla okullarda öğrendiklerini tekrar etme imkânı buldukları ve yeni şeyler öğrendikleri düşünülebilir. 
Yılmaz (2012) çalışmasında "Türkçe çocuk gazeteleri de bir bakıma rüşdiyelerdeki eğitim anlayışını takip ederek ahlaklı bireyler yetiştirme hedefi gütmüştür. Gazeteler özellikle rüşdiye talebelerine yönelik kıssadan-hisse çıkarılacak hikâyelere büyük yer vermiştir. Anlatılan hikâyelerde ahlaklı bireylerin vasıfları geleneksel roller çerçevesinde vurgulanmış, çocukların anne ve babalarına, hükümete, yaşlılara, birbirlerine saygılı davranmaları gerektiği s1k sık tekrar edilmiştir" ifadeleriyle dönemin çocuk gazeteleri hakkında bilgi verir. $\mathrm{Bu}$ bilgiler 1şı ğında Sadâkat/Etfâl'in de hem çocukların okul derslerine yardımcı olacak hem de onların kişisel ve ahlaki yönlerini destekleyebilecek bir kaynak niteliği taşıdığı söylenebilir. Zira gazetede ana-babaya hürmet, birlik olma, çalışkan olma, dostluk, edepli olma, eğitim-öğretime önem verme, inançla ilgili değerler, kibirden uzak durma, sağlıklı olmaya özen gösterme, saygılı olma, tutumlu olma, ulusal değerleri tanıma, yardımsever olma, zamanı doğru kullanma (Ercan 2014: 27-55) gibi değerler de metinlerle çocuklara kazandırılmaya çalışılmıştır.

\section{KAYNAKÇA}

ALTAY, İbrahim (2012), "Osmanlıca çocuk dergileri”, http://www.sabah.com.tr/Cumartesi/2012/01/07/osmanlica-cocukdergileri

BALCI, Ahmet (2012), “Türkiye'de Çocuk Edebiyatı Üzerine Hazırlanan Lisansüstü Tezler Hakkında Bir Meta-Analiz Çalışması" Mustafa Kemal University Journal of Social Sciences Institute. 9 (17), s. 195-206.

CIRAVOĞLU, Öner (1999), Çocuk Edebiyatı, Esin Yayınevi, İstanbul.

DEMIRAY, Kemal (1973), Türkçe Çocuk Edebiyatı, Milli Eğitim Basımevi, İstanbul.

DUMAN, Hasan (2000/1), Osmanll-Türk Süreli Yayınlart ve Gazeteleri 18281928, I.Cilt, Enformasyon ve Dokümantasyon Hizmetleri Vakf1, Ankara.

DUMAN, Hasan (2000/2), Osmanll-Türk Süreli Yayınlart ve Gazeteleri 18281928, II. Cilt, Enformasyon ve Dokümantasyon Hizmetleri Vakfi, Ankara.

EMIROĞLU, Öztürk (1992), Tanzimat'tan 1928'e Kadar Yayımlanan Çocuk Gazete ve Dergileri Üzerine Bir Inceleme, Yüksek Lisans Tezi, Erciyes Üniversitesi Sosyal Bilimler Enstitüsü, Kayseri.

ER, Sırrı (2012), "Çocuk Dergileri”, http://www.kalem.biz/akyazi.asp?islem=yazidetay $\& i d=2219 \& d b=20 \&$ ko nusu $=\%$ C7ocuk\%20Dergileri 
ERCAN, Aliye Nur (2014), Etfâl Gazetesinin Metin ve Değerler Eğitimi Açısından İncelenmesi, Yüksek Lisans Tezi (Basılmamış), Necmettin Erbakan Üniversitesi Eğitim Bilimleri Enstitüsü, Konya.

ERTUĞ, Hasan Refik (1970), Basın ve Yayın Hareketleri Tarihi, Yenilik Basımevi, İstanbul.

İNUĞUR, Mehmet N. (2005), Basın ve Yayın Tarihi, Der Yayınları, İstanbul.

KAPLAN, Mehmet (2007), Kültür ve Dil, Dergâh Yayınları, İstanbul.

KARABIÇAK, Yusuf Ziya (2011), “Angeliaforos Çocuklar İçin Ve Osmanlı Devleti'nde Yayınlanan Diğer Çocuk Gazeteleri: Modern Çocukluk Söyleminin Oluşumu", Osmanlı tarihi. Toplumsal Tarih 215. Kasım 2011, s. 2-11.

KASAP, Ayşe (2011), Evvel Zaman İçinde Çocuk Dergileri 1869-1928 Yılları Arasında Yayınlanan Osmanlıca Çocuk Dergileri, Sultanbeyli Belediyesi, İstanbul.

KIBRIS, İbrahim (2002), Uygulamalı Çocuk Edebiyatı, Eylül Yayınevi, Ankara

KÜR, İsmet (1991), Türkiye'de Süreli Çocuk Yayınları, AKM Yayını, Ankara.

OĞUZKAN, A. Ferhan (2010), Yerli ve Yabancı Yazarlardan Örneklerle Çocuk Edebiyatı, Anı Yayıncılık, Ankara.

OKAY, Cüneyd (1998), Osmanlı Çocuk Hayatında Yenileşmeler 1850-1900, Kırkambar Yayınları, İstanbul.

OKAY, Cüneyd (1999), Eski Harfli Çocuk Dergileri, Kitabevi, İstanbul.

ÖZDEMIR, Mehmet (2005), “Türkiye'de Çocuk Edebiyatı Kültürü Açısından Eğitim Fakültelerinde Okutulan "Çocuk Edebiyatı" Dersleri", Sakarya Üni Ĕg. Fak. Dergisi Sayı 9, s. 110-119.

PINARCI, Gülden A. (2013), "Çocuk Dergileri”, http://ebulten.library.atilim.edu.tr/sayilar/2013-06/okuma.html

Selim Nüzhet (1931), Türk Gazeteciliği, Devlet Matbaası, İstanbul.

SEVER, Sedat (2008), Çocuk ve Edebiyat, Tudem Yayınları, İzmir.

ŞENTÜRK, Sevim (2011), "Çocukların geçmişte ne yaptığı bu sergide!"

http://www.zaman.com.tr/cumaertesi_cocuklarin-gecmiste-ne-yaptigi-busergide_1206340.html

ŞİMŞEK, Hüseyin (2001), "XIX. Yüzyıl Çocuk Dergiciliği ve Eğitsel İşlevleri Üzerine”, Milli Eğitim Dergisi. Sayı 151, Temmuz, Ağustos, Eylül. http://dhgm.meb.gov.tr/yayimlar/dergiler/Milli_Egitim_Dergisi/151/simse k.htm

ŞIMŞEK, Tacettin (2002), Çocuk Edebiyatı. Rengârenk Yayınları, Ankara. 
TOPUZ, Hıfzı (2003), II. Mahmut'tan Holdinglere Türk Basın Tarihi, Remzi Kitabevi, İstanbul.

YALÇIN, Alemdar ve AYTAŞ, Gıyasettin (2003), Çocuk Edebiyatı, Akçağ Yayınları, Ankara.

YILMAZ, Eray (2012), "Tanzimat Dönemi Türkçe Çocuk Gazetelerinde Ahlak, İlim Ve Milliyetçilik (1869-1876)", Tarih ve Toplum Yeni Yaklaşımla, Say1 15, Güz. 